\title{
BLogging IDENTITY: How L2 LEARNERS EXPRESS THEMSELVES
}

\author{
FUJII Kiyomi \\ Kanazawa Institute of Technology, Japan \\ kfujii@neptune.kanazawa-it.ac.jp
}

\begin{abstract}
This study discusses language learning and identity, particularly pertaining to intermediateadvanced-level Japanese-language learners, focusing on their target language and identity expression through their interactions with peers and Japanese college students. When learners of Japanese express their identities while interacting with others in their target language, they feel a gap between the self-image they want to present, and the image they are capable of presenting in Japanese (Siegal, 1994, 1995, 1996). Along with adjusting their L1 and L2 usage depending on their interlocutor (Kurata 2007), learners also use different sentence-ending styles depending on the role they want to assume (Cook 2008). By conducting a case study, the present inquiry attempts to address how learners of Japanese express their identities through blog conversations, focusing on their language choice and expressions. Results suggest that participants use the formal endings for self-presentation and projection of their student and classmate identity. However, when expressing emotion some students preferred informal endings, or sentence-final particles.
\end{abstract}

Key words: SLA; identity; blog; sentence final expression; JFL

\section{Povzetek}

Študija obravnava povezavo med učenjem jezika in identiteto in se še posebej osredotoča na študente japonščine na srednjem in višjem nivoju ter njihovim ciljnim jezikom in izrazi identitete $v$ pogovorih s prijatelji in japonskimi študenti. Splošno znano je, da študent japonščine ob izražanju svoje identitete $v$ tujem jeziku občuti razliko med podobo, ki si jo želi orisati, in podobo, ki jo je sposoben orisati v japonščini (Siegal, 1994, 1995, 1996). Poleg tega govorec prilagaja tako materni kot tudi tuj jezik, hkrati pa izbira med različnimi oblikami na koncu stavkov, s katerimi nakazuje govorni stil in prevzeto vlogo v komunikaciji (Kurata 2007). S študijo primerov raziskava razkrije, kako študenti japonščine razkrijejo svojo identiteto preko blogov. Raziskava se osredotoča predvsem na izbiro jezika in izraze. Rezultati kažejo, da sodelujoči uporabljajo formalne oblike za samopredstavitve in napovedi identitete sovrstnikov, medtem ko so neformalne oblike in členki na koncu povedi priljubljeni pri izražanju čustev.

Ključne besede: usvajanje tujega jezika, identiteta, blog, izrazi na koncu povedi, poučevanje japonščine kot tujega jezika 


\section{Introduction}

Our capacity to influence language learners beyond the classroom has increased with developments in internet technologies and SNS. Based on an activity using these innovative tools, in this paper, I will investigate how students of the Japanese language, maintain their self-identities using their target language, rather than native language, in their interactions with Japanese native speakers in an online social network context.

Much research has been conducted in the acquisition of Japanese as a second language. However, few studies have investigated how learners of Japanese express their identities in their second/foreign language while they interact with others in that second/foreign language (Japanese). In this paper, I will investigate how learners of Japanese express their identity through their blog conversations by conducting a case study. First, I will discuss language learning and identity and review previous research in terms of $L 2$ learners of Japanese, particularly intermediate-advanced-level learners, focusing on the L2 language and their identity expression through their interactions.

\section{Language and identity}

\subsection{Language socialization and identity}

Japanese children acquire "language socialization ${ }^{1 "}$ skills through interaction at home and at school and construct their identity with the use of shifting desu/masu form and plain forms. In elementary school, children explore being socialized by participating in classroom interaction. In particular, they learn how to interact and listen to opinions of others and speak as members of a group from attentive listening (Cook, 1999).

Clancy (1999) pointed out that Japanese children learn how to express their feelings in their culture and mother-child interactions develop children's linguistic social skills. When people in a society interact with others "their actions are influenced by their conceptions of their own and other's social status (Schieffelin \& Oche, 1986, p.6)."

To view identity from our language socialization, Bucholtz and Hall (2005) proposed a framework that states:

Identities may be linguistically indexed through labels, implicatures, stances, styles, or linguistic structures and systems; identities are relationally constructed through several, often overlapping, aspects of the relationship between self and other, including similarity/difference, genuineness/artifice and authority/ delegitimacy; and identity may be in part intentional, in part habitual and less

\footnotetext{
1 "socialization through language and socialization to use language (Schieffelin \& Oche 1986, p.2)"
} 
than fully conscious, in part an outcome of interactional negotiation, in part a construct of others' perceptions and representations, and in part an outcome of larger ideological processes and structures. (p. 584)

Nakamura (1999) studied how Japanese children acquire language socialization, focusing on the addressee honorific desu/masu form. This is a longitudinal study of the interaction between 30 Japanese children, from 18 months to 6 years old, and interaction with interlocutors such as mothers, siblings, peers, and unfamiliar adults. The data show that children start using the addressee honorific form when they are between 18 months and 2 years old. Her study illustrates that addressee honorifics are "one of the easiest forms of polite language for young children to acquire" ( $p$. 509). She categorized children's desu/masu usage into four categories:

(1) "repetition/direct quotation" is when children repeat or quoted adults' utterances, especially in their beginning stage; (2) "responding to the level of the interlocutor" is when children answer formal questions; (3) "presentation/ identification" is when children present their identification; and (4) "narrative function" is when children use desu/masu forms while retelling stories which they are familiar with. (Nakamura, 1999, p. 509)

She points out that children are sensitive to the social context, because they use desu/masu forms when they interact with unfamiliar adults, switch between desu/masu form and plain forms when they role-play, and use desu/masu forms when they need to maintain formality.

Cook (1996) also studied the usage of the desu/masu form and its counterpart, plain form, both at home and in elementary school. The data collected from three families illustrate that at home, children use desu/masu forms when they show their responsibilities as members of the family, and also when they are engaged in roleplay of a character such as a doctor. The data collected from four different elementary schools' third and fourth grade classes indicate that children create presentation speech when using desu/masu form in an on-stage setting. Cook points out that the desu/masu form is used as an index of the discipline mode, and the plain form is used as an index of spontaneous modes. The data also show that students use the plain form to their teachers. Cook claims this is because "the students do not understand this form [the addressee form] as an index of politeness or [they are] socially lower status" (p. 189). Both teachers and students use the desu/masu form for public display. These interactions facilitate children's socialization processes, which are created by using the desu/masu form and plain forms in the uchi and soto contexts. She speculates that switching between the desu/masu and plain forms "both at home and school promotes the acquisition of the culturally significant concepts of uchi 'inside' and soto 'outside'" (p. 194).

This raises the question of how can learners of Japanese acquire this language socialization and how they construct their identity using L2? Can they acquire it from social environments such as home and school, like Japanese children do? In the next 
section, I will review previous studies of Japanese language learners and their language socialization and identity.

\subsection{Japanese language learner's language socialization and identity}

Previous studies of learners of Japanese and their interaction in home-stay environments (Hashimoto, 1993, Marriott, 1995) indicate that students who learn Japanese in Japan receive a massive amount of input and try to interact native speakers. Two more studies of learners of Japanese as a foreign language report classroom interaction routines provide language socialization even in a non-targetlanguage environment (Kanagy, 1999, Ohta, 1999). However, these studies focus on linguistic features and not on learners' language socialization and identity and the related language use.

Armour (2003) analyzed the case of two Australian students who have studied the Japanese language and participated in a home-stay. He investigated how "multiple self-presentations are scaffolded by the ability to make meaning in Japanese as an additional language" and how those learners process identity slippage. His discourse data illustrate how learners change their views of Japan and gain intercultural competence, and how this change constructs their narrative space; to identity slips and express multiple self-presentations.

Siegal (1994, 1995) studied four adult women Karen, Sally, Mary, and Arina, learning Japanese in Japan, including their acquisition of sociolinguistic competence and use of honorifics. The research focused on language use associated with the image the students wanted to present, and their individuality. Unlike the two studies above, Mary and Arina were aware of the different speech styles associated with expressing politeness. Although Mary wanted to express her politeness, her data indicate inappropriate usage of the epistemic modal desho, and formulaic routine expressions such as 'I'm sorry' sumimasen. The research focused on language use associated with the image the participants wanted to present, and subjectivity. As Seigal (1996) described, Mary often thought she could not express certain 'subtleties' like she could in English. In the case of learners wanting to express deference or politeness, this gap seems larger for an adult learner than for a younger student. However, an interlocutor did not necessarily view pragmatic inappropriateness as failure (Siegal, 1995, 1996). Her further research (1996) concludes that a learner's subjectivity plays an important role.

Cook (2008) investigated conversation between nine learners of Japanese and their host families. She analyzed how learners socialized using masu form and how their host families express their identity through the use of the masu form. She analyzes dinner table conversation between a learner and host family and focused on two ways, a learner and host family, identity constructions. The data illustrate that frequency of the use of the masu form are relatively small. However, when they are used host families construct their social identity, such as host parents. They use the masu form when "(1) uttering set formulas, (2) highlighting various aspects of their 
social identities associated with the home-stay context and (3) foregrounding identities of speakers in reported speech" (p. 200). Learners also use the masu form when they construct identities such as "English teacher" and "presenter." Cook argues that the masu form is "an important linguistic resource for expressing a variety of social identities and it can be used to socialize learners to become speakers who can competently display a range of social identities" (p. 201).

These studies focus on language and identity in immersion situations, in which learners can interact with interlocutors face to face. In the next section, I will review L2 learner's language socialization in Internet environments.

\subsection{Language socialization on Web 2.0 and L2 identity}

Noting the exceptional growth in students' use of Web 2.0 innovations such as blogs, instant messaging, and social networking, we as language instructors began to explore ways to incorporate these technologies in language pedagogy. Now, online instructional tools are widely used in language learning. Lam (2004) studied two Chinese female teenagers who emigrated to the U.S. from China with their families. They were both having trouble to immerge their English speaking peers. They were both willing to learn English, so they joined an online chat room in which native Chinese speakers use English to communicate. The data were collected through their chat room conversations with other native Chinese speakers who used English to chat. Lam points out that hey use romanized Chinese for the sentence-final particles and honorifics to address each other, to show their emotions and construct social identities.

Kurata (2007) investigated a college student who studied Japanese and the interactions with his friends. Data were collected throughout their conversation and analyzed with focus on patterns of language choice. Kurata pointed out that the learner's language choice was influenced by many factors and these factors appeared to be related to the learner's and interlocutor's identity. She indicates that learners choose their language use (English or Japanese) according to their interlocutor's L2 language ability. However, Kurata's study only pointed out learners' language choice between Japanese or English. Consequently, my research question asks how learners' language choices are determined in terms of expression tools of their identity through the target language and the class blog space.

\section{Data and methodology}

This study focuses on Japanese language learners, their language choice, and expressions used to construct their identity. The participants in this study are five students among 13: five females and one male, from the third-year Japanese course. They completed four to six semesters of Japanese (one student could not get into the third-year class because it was full, so this student retook the second-year course, and 
some students tested out the first semester of the third-year Japanese course) and are enrolled in the second semester of the third-year Japanese course. The participants were chosen by the researcher for the judgment sampling since they met the following conditions: they all had over two years of formal study of Japanese and they participated in the class blog activity. They all posted their free messages and posted comments to other students.

The data were collected through the third-year Japanese class blog. All participants were required to create a blog as a course assignment from last semester. All individual blog pages were posted to the third-year Japanese course blog and students could visit their classmates' blogs. They exchanged comments with Japanese college students who study English in Japan. The Japanese college students' blog pages were posted to their English class blog and the link posted to the thirdyear Japanese class blog as well. The third-year Japanese class blogs were all written in Japanese, including students' posted messages and comments, while the native Japanese college students' blogs were all written in English. In this study, I focus on the third-year Japanese class blog, which was written in Japanese.

Students who joined the third-year Japanese class this semester, created a blog page at the beginning of the semester. All students needed to post their sakubun 'essay' after they received their corrected final draft. Therefore, sakubun have been collected and rewritten. There were four sakubun assignments in this course, and the topics were assigned. Students were also asked to post messages at the end of each chapter covered in the textbook, but this started from chapter 11 and two chapters were covered after the free message assignment started this semester. However, they didn't have any restrictions or requirements for their messages and they did not receive any grade, so some students did not post any message. The instructor did not post any messages to class blog because doing so would have altered the social dynamic.

The analysis focuses on students' use of sentence endings (formal, desu/asu form, or informal, plain form, endings) and sentence-final particles from their free posted massage and participants' comments to others and response to others' comments, which included response to Japanese college students' comments as well. In addition, the questionnaire was used to ascertain the participants' perceptions of the sentence endings. The participants were asked to mark perceptions of the sentence endings, indicating characteristics like: femininity/masculinity, polite/nonpolite, and weak/strong impression. 


\section{Results and discussion}

\subsection{Initial observation}

First, I will present the participants' blogs and their self-introductions from the initial observation, specifically analyzing how they introduce themselves and what projection we can observe in the introductions and the blogs themselves.

Since all students have formal language instruction, they all begin with their name, year in school, where they are from, and what they like. All sentences are written with formal sentence endings and all of them mention their reasons for studying Japanese. This was their first post. It indicates that all of them show the "student" persona and seem to get a lay of the land, just like they would on the first day of class. Since all of the participants are juniors and seniors, they seem to consider their post-graduation plans. Two junior students did not talk about their future, but the rest of the participants clearly mention their plans after graduation.

All participants changed their blog backgrounds from the default to a custom theme background with more colors, or to something more stylish. In addition, one blog included pictures of the student and her boyfriend. This differentiates their blogs from others and shows individuality through the manipulation of the blog theme. It is reasonable to assume that they may be aware of their language limitations and use other strategies to set themselves apart from their classmates.

\subsection{Sentence endings}

There are 106 sentences total including one greeting from the posted messages. 74 $(69.8 \%)$ sentences end with formal endings, desu/masu form, and 32 (30.2\%) sentences end with informal endings (Table 1). This is probably because formal endings are introduced from the first year, allowing students time to practice usage of these forms in class from the first-year to the third-year course, except when they practice casual forms. Another possibility is that students use formal endings for public display through this space. Aforementioned studies, Cook $(1999,2008)$ and Nakamura (1999), investigated Japanese L1 speakers' language socialization and found they used the desu/masu form to index their mode, for example when giving a presentation. 
Table 1: Posted messages sentence endings

\begin{tabular}{|c|c|c|c|}
\hline & $\begin{array}{l}\text { Formal } \\
\text { endings }\end{array}$ & $\begin{array}{l}\text { Informal } \\
\text { endings }\end{array}$ & $\begin{array}{c}\text { Total } \\
\text { sentences }\end{array}$ \\
\hline & $\%$ & $\%$ & n \\
\hline S1- $1^{\text {st }}$ message & $87.5(14)$ & $12.5(2)$ & 16 \\
\hline $2^{\text {nd }}$ message & $8.3(1)$ & $91.7(11)$ & 12 \\
\hline S2-1st message & $100.0(5)$ & $0(0)$ & 5 \\
\hline $\begin{array}{c}\text { 2nd } \\
\text { message }\end{array}$ & $100.0(6)$ & $0(0)$ & 6 \\
\hline S3-1 ${ }^{\text {st }}$ message & $87.5(7)$ & $12.5(1)$ & 8 \\
\hline $2^{\text {nd }}$ message & $0(0)$ & $100.0(7)$ & 7 \\
\hline S4-1 ${ }^{\text {st }}$ message & $92.3(12)$ & $7.7(1)$ & 13 \\
\hline $2^{\text {nd }}$ message & $100.0(7)$ & $0(0)$ & 7 \\
\hline Total & $69.8(74)$ & $30.2(32)$ & 106 \\
\hline
\end{tabular}

() numbers of sentences

One participant used formal sentence endings exclusively, other participants used mixed forms. In the case of the participants who used both formal and informal endings, their later messages used a more casual style than the message they posted initially. It seems they created classmate relationships, causing them to shift to plain form in order to construct a friendly environment. This can be observe in their posted message content as well. All participants posted their recent, or weekend, activities and there are no posted messages that state their opinions in the manner of the sakubun assignment. However, the posted messages show what they thought about, instead of only stating their experiences, and these experiences are more private. For example, Student 1 (S1) posted the first message about his girlfriend who recently returned to her country. His second posted message stated how he spent spring break and talks about how he feels about his girlfriend, since it has been about one month since she left. Another example is that of Student 2 (S2), who posted a message about her class project, but the second message was about her favorite song and she uploaded a video to share with others.

Most participants used mixed forms and often the sentence ending shifted from formal to informal ending as demonstrated in the following examples:

(1) From S4's first posted message

1. Demo daatuno wa yappari joozujanai node taitei taagetto wo hazushimashita. 'However, I'm not good at darts, so usually I didn't hit the target.'

2. Demo, sono futatsu no geemu wa tanoshikatta.

'However, those two games are fun.'

3. Sorekara, geemu wo shitekara tomodachi no uchi ni itte sukoshi osake wo nomimashita.

'After that, after the game, I went to my friend's house and drank alcohol.' 
In Example (1), S4 posted her weekend activities. Line 1 and 3 are activities she did, but in line 2 are her thoughts about games played. She shifts the ending from formal to informal ending to express her thought process.

(2) From S 5's first posted message

1. xxx-san wa xx-chan ni "kanojo to kekkon wo shiro!" to iimashita! ' $x x x$ told $x x$ to "marry her!"'

2. Bikkurishita! '[I was] surprised!'

3. Watashi wa hazukashikatta desu yo! “I was embarrassed!”

In this example, S5 discussed her and her boyfriend's usual Friday activities. They typically go to a coffee shop and play chess there. Last Friday, when they went there, they ran into her German friend who is older than them and that friend told her boyfriend to marry her, as stated in line 1 . S5 ended her reaction with a non-polite ending saying bikkurishita with an exclamation mark.

(3) From S1's first posted message

1. Maa...kore wa daigakusee no jinseedesu yone. 'Well....this is a college student' life isn't it?'

2. Kanashii toki mo aru kedo itsuka tanoshiitoki mo aru. 'There are sad times, but there are fun times as well.'

3. Shiawasena hi ga kanarazu kuru node mattemasu. 'Happy days are definitely coming, so I will wait.'

In the above example S1 shared his recent experience of having his girlfriend returning to her home country, and these are the final three lines. S1 chose an informal ending for line 2. Compared to line 1 and 3 , he is saying this himself and it seems he has a strong feeling that he wants to believe.

As illustrated in above examples, in the case of shifting from formal to informal endings, the participants use informal endings to express their emotions, thoughts, and strong beliefs. Conversely, participants use formal endings to show their "student" persona to other classmates and informal endings to show their insight. In the posted message the participants used formal endings more than informal endings since this is more like a presentation, especially the first posted message. The characteristics of posted message and leaving comments and responding to others' comments are slightly different. However, the results still indicate that the participants used formal endings more than informal endings.

There are 326 sentences from blog comments (99 sentences) and response to others (227 sentences) comments. 283 (86.8\%) sentences end with formal endings, desu/masu form, and $43(13.2 \%)$ sentences end with informal endings as in Figure 1. Beside the fact that formal endings are introduced from the first year of language study and the students are familiar with using them, a possible reason that the formal 
endings are used more than the informal endings is that participants are being polite to their classmates. There is no discernable pattern that comments have more formal endings than do responses to comments, or visa versa.

Although the informal endings were used in most of the sentences and they are used more than posted messages, comments and response to others comments are more conversational than posted messages. In the posted messages participants displayed their "presentation" mode using formal endings.

There are a few reasons for this. First, unlike the posted message (one question sentence), there are 21 question sentences included in the comments and responses to others' comments. The questions are related to the posted messages and participants who were asked questions response to those comments. Secondly, they express more their thought and feelings. However, in the posted message, when they express their thought and feelings they used the informal endings. If the content of the comments include more thought and feelings, the informal endings sentence should be more, but there are more formal endings. They use other strategies such as the sentence-final particles to express their thoughts and feelings, while being polite to other classmates using the formal endings. In the next section, I will discuss how they use other strategies to socialize with other classmates.

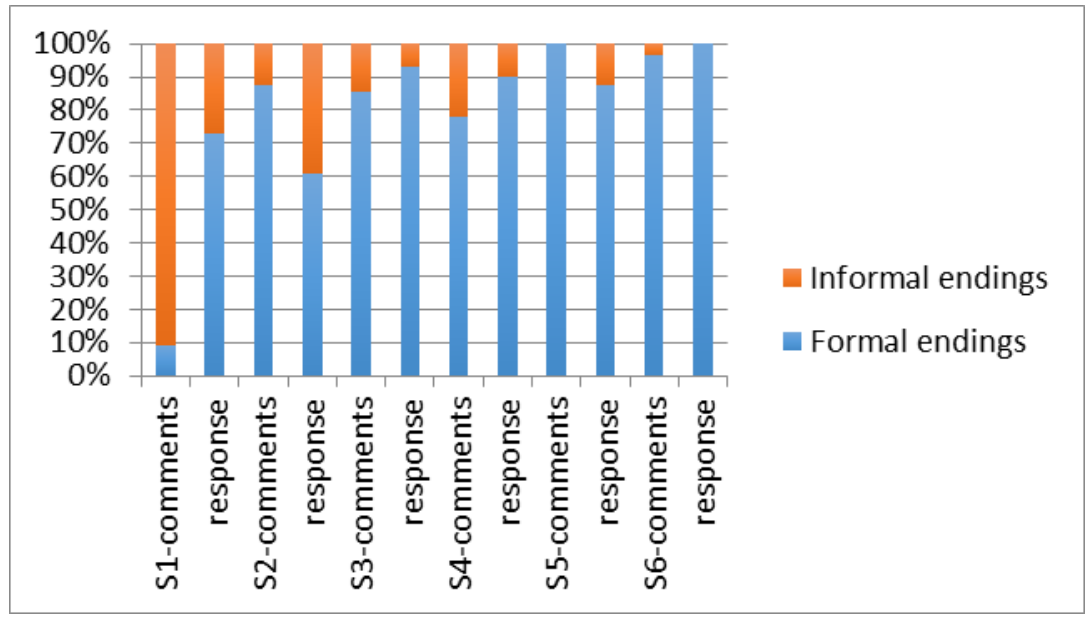

igure 1: Sentence endings from comments and response to others comments

\subsection{Sentence-final particles}

Sentence-final particles used in the posted messages were limited in number; ne: 7 , yo: 2, yone: 2, na: 2. Other ending are kamo, kedo, and dakara. Kamo derives from kamoshirenai, 'it might be,' by dropping shirenai. Kedo means 'although' in English, and is usually followed by a sentence presenting a contrast. There are also desho to seek agreement. 
Japanese sentence-final $n e$ is generally used to express (1) agreement, (2) confirmation, (3) cooperation, and (4) affective command (Cook, 1990). It is also used when the speaker has less information and more feeling than information whereas yo is used when the speaker has more information and is more forceful (Maynard, 1997). In the textbook that participants used, ne is introduced in the following manner: "when the speaker is seeking the listener's agreement or confirming a fact. It is similar to isn't it? In English," and yo is introduced as: "when the speaker wishes to emphasize to the listener that he/she is imparting completely new information. Like you know in English" (Hatasa, Hatasa, \& Makino, 1998, p.79). As seen in line 3 in Example (2), Watashi wa hazukashikatta desu yo!, S5 emphasizes how much she was embarrassed.

(4) From S3's first posted message:

Projekuto to shite nikki wo kakukotoni narimashita ga taninno nikki nante tumarai desu yone.

'I decided to write a diary as my project, others' diaries are pretty boring, aren't they?'

The choice between yo and ne is in a complementary functional relationship: information and interaction (Maynard, 1997). However, yo signals stressing information and participant's expectation of success to exchange information, but if the exchange is not successful the speaker's emotion will "include an impression of self-centeredness and a lack of consideration and cooperation (Maynard, 1997, p. 90). In line 3 in Example 3, Maa...kore wa daigakusee no jinseedesu yone, and in Example 4 , in both of these cases ne and yo work, but yo sounds rather strong and ne sounds like an attempt at reducing his responsibility (Ohta, 1999). Therefore, they used both and make the effect of yo softer.

The participants learned the particle $n a$ as in $\sim k a n a / \sim k a s h i r a$. In the textbook, they are introduced in the following manner: "when the speaker is asking himself or herself about something" and "they express the speaker's monologue question, I wonder ." Again, "the expression kana can be used by both males and females, but kashira is used only by females," and "they should not be used with someone with a superior social status because they are used in fairly informal speech" (Hatasa, Hatasa, \& Makino, 2000, p.65). The participants use the particle na to express their thoughts to others as in example (5) and (6).

(5) S1's first posted message

1. Anmari kankoku jin no tomodachi ga inai $n$ da kedo semete ichido tameshite mitai 'I don't have many Korean friends, but I would like to try at least once.'

2. Nantoka naru na...

'I will be fine, yeah?'

(6) S3's second posted message

1. Nado kiitemo namida ga deru gurai iikyoku da to omou.

'I think it is a good song, like every time I hear it, I get choked up.'

2. Wakaimono no ongaku mo iikedo toki niwa konna kyoku mo iina.

'Young people's music is fine, but sometimes a song like this is nice, ain't it?' 
Table 2: The sentence-final particles in posted messages, comments and responses to others' comments

\begin{tabular}{|c|c|c|c|c|c|c|c|c|}
\hline & ne & yo & yone & na & others & emoticon & \multicolumn{2}{|c|}{ Total } \\
\hline S1-message & & & 1 & 1 & & & 2 & \multirow{3}{*}{10} \\
\hline comments & 2 & 1 & & 3 & 1 & & 7 & \\
\hline response & & 1 & & & & & 1 & \\
\hline \multicolumn{8}{|l|}{ S2- message } & \multirow{3}{*}{9} \\
\hline comments & 1 & & & & & 1 & 2 & \\
\hline response & & & & & & 7 & 7 & \\
\hline S3- message & 1 & & 1 & 1 & 3 & & 6 & \multirow{3}{*}{39} \\
\hline comments & 3 & & & & 1 & 3 & 7 & \\
\hline response & 10 & 2 & & 1 & 1 & 12 & 26 & \\
\hline S4- message & 5 & & & & & & 5 & \multirow{3}{*}{17} \\
\hline comments & 2 & & & & & & 2 & \\
\hline response & 5 & 5 & & & & & 10 & \\
\hline S5- message & 1 & 2 & & & & & 3 & \multirow{3}{*}{9} \\
\hline comments & 3 & 1 & & & & 2 & 6 & \\
\hline response & & & & & & & & \\
\hline S6- message & & & & & & 1 & 1 & \multirow{3}{*}{24} \\
\hline comments & 8 & 2 & & & 4 & 3 & 17 & \\
\hline response & 2 & 1 & & & 2 & 1 & 6 & \\
\hline Total- message & 7 & 2 & 2 & 2 & 3 & 1 & 17 & \multirow{3}{*}{108} \\
\hline comments & 19 & 4 & 0 & 3 & 6 & 9 & 41 & \\
\hline response & 17 & 9 & 0 & 1 & 3 & 20 & 50 & \\
\hline
\end{tabular}

Compared to the posted messages, comments and responses to others' comments include more sentence-final particles as well as emoticons. Comments include, ne: 19, yo: 4, na: 3 and other ending are kedo and desho. Response to others comments include, ne: 17, yo: 9, na: 1 and one other ending is desho. Both comments and responses include emoticons, comments (9) and responses (20). They also used the smile mark, kanji 笑 'laugh,' and one pictogram abbreviation.

(7) S3 response to classmate's comment

1. Henji ga osokunatte sumimasen $\rangle_{-}<$; ;

'I'm sorry for the delay in my response'

2. Guguru shite mita n desu ka!

'Did you google me?'

3. Hai, twitter yatte masu.

'Yes, I do twitter." 
4. Ima wa follower ga kankoku no tomodachi bakkari de kannkokugo dake kaitemasuga, moshi xx-san ga follow shitekureba nihongo ya eigo mo kakeru shikai ni naru desho:)

'Now, followers are all Korean friends, so I write in Korean, but if xx-san follows me, I can be a host that writes Japanese or English, can't I?'

5. Ego demo nihongo demo iindesu.

'Either English or Japanese is fine."

6. Koe kakete kureru nara ureshii :)

'If you call me, I will be happy."

In Example 5, S3 used emoticons to show her emotions. In line 1, she apologized with formal ending using a formulaic expression and used the emoticon, >_< ; ; to show emotion and friendliness. In line 4 and 6 , she used the smile mark as well. She used the formal sentences for all sentences, but she also managed to create friendly atmosphere using emoticons.

Another example is kanji emoticon, 笑 'laugh'. Before Example (8)'s conversation, S6 left her comment for S3's posted message which was S3's self-introduction. S6 comments S3's Japanese is very good. In the following conversation, S3 and S6 were talking about Japanese language for Korean learners.

(8) S3 response S6's comments

1. S3: $x x$-san to yonde ii desu $k a$.

'May I call you xx-san?'

2. Yoroshiku onegaishimasu :)

'Nice to meet you.'

3. Watashi wa kankoku no shusshin desu kara dounimo nihongo ga hoka no hito yori yasashiidesu.

'I'm from Korea, so I kinda feel Japanese is easy for me than other people.'

4. Kankokugo to nihongo no bunpou ya tango nado ga sugoku nitemasu yo. 'Structure and vocabulary of Korean language and Japanese language are very similar, you know.'

5. Chotto zuruinjanai kana to omottemasu (笑).

'I think it is unfair (laugh)'

6. Natsuyasumi ni nihon ni ikun desu ne!

'You are going to Japan on the summer vacation, aren't you!'

7. lina...

'lit. It is good. [I'm jealous].'

8. Watashi wa nihon no gakkoo ni ittakoto ga nai node xx-san ga urayamashii (笑).

'I've never been (attended) a Japanese school, so l'm envy you/jealous, xxsan (laugh).'

(five sentences continue)

S6 response again 
9. S6: Zehi, $x x$ to yonde kudasai.

'By all means, call me $x x . '$

10. Soudesune, kankoku kara kita tomodachi mo nihongo wo benkyoushite te, suggoku jouzu to omoimasu.

'Well, my friend who came from Korea studying Japanese and I think she is very good at it.'

11. Zurui to omowanai n desu nedo, nanka mukatsuku desu ne. 笑

'I don't think it is unfair, but I'm a little pissed, right, laugh.'

(four sentences continue)

In Example (6), S3 and S6 used the kanji emoticon, 笑 'laugh' in line 5, 8 and 11. In line 5, after S3 states Chotto zuruinjanai kana to omottemasu, 'I think it is unfair,' she uses the kanji emoticon, 笑. Since she used zurui as she feels she is cheating, she makes this as a joke. In line 8, S3 again use the kanji emoticon, 笑 when she express her jealous feelings to make it as joke. When S6 responded to S3, she express her thought saying zurui to omowanai $n$ desu nedo and she said nanka mukatsuku desu ne. S3 used a word mukatsuku which original meaning is feel nausea, but here it is used as 'piss me off' or 'bite me.' She didn't say mukatsuki masu which is correct way to conjugate mukatsuku since it is verb, but instead she used as a noun and in katakana. It seems she did it on purpose and used mukatsuku as a expression since not many situation in the real life to use this polite way, mukatsukimasu. Mukatuku is insulted expression and rather strong, so she added desu to show politeness and ne to soften what she expressed. She also used the kanji emoticon, 笑 to show it is a joke. If she is mad she could have used the kanji emoticon, 怒 instead.

Above examples indicate that participants use the sentence final particles and emoticon to express their feelings. However, they also try to keep their manner and friendliness toward their classmates.

\section{Conclusion}

In this study, I investigated how learners' language choice is determined in terms of expression tools of their identity through the target language and class blog space. The study indicates that participants use the formal endings to present themselves and express their identity as students and classmates. However, when they want to express their emotion, some use the informal endings and others use the sentence final particles. The study also found that participants are using other strategies, besides the linguistic, to maintain their identity, or perhaps to compensate for their linguistic limitations, by using the sentence final particles and emoticons.

Although the data include participants' responses to Japanese college students, for further research, the interlocutor's perspective of acceptability toward people who don't have many experiences of contact with non-Japanese needs to be explored. 
Since this is a pilot study, the data collected were rather small, and for further research more data should be collected. This study focused on learners of Japanese language use and identity expressions. However, other factors need to be considered when we research learner's Japanese and their identity projection: one such factor is gender. Many previous studies examine the differences between women's and men's speech (Shibamoto, 1985, Ide, 1982, 1997, 1999, Ide and Yoshida, 1999). On the other hand, studies also confirm that usage of sentence final particles differs depending on the individuals, time, and context (Matsumoto, 2002, Okamoto, 1997, 2002, 2004, Ozaki 1998). Another factor is the language-learning environment. Matsuda (2014) conducted research using Facebook birthday message data and the results, arrived at through correspondence analysis, showed that mid to advanced Japanese learners' language use was close to middle-aged Japanese women. This result correlates with the fact that the majority of Japanese language teachers represent this demographic. Matsuda's research suggests how learners' learning environment affects their language use, and the next iteration of the present study will include more consideration to this influential element.

Finally, individual differences need to be considered. The participants' motivations and learning strategies are different for each subject. Furthermore, it is also important how sensitive or aware the learners are when it comes to usage of the sentence final particles and sentence endings, for example.There have been few studies done on how learners develop language socialization in an online environment in regards to Japanese as a second language. More quantitative research needs to be done on acquisition of language socialization, especially in the area of L2 learner's identity.

\section{References}

Armour, W. (2003). 'Nihonjin no yoo to omoimashita' (I think I'm like a Japanese): Additional Language Learning and the Development of Multiple Selves. Asian Ethnicity. 4 (1), 115-128.

Bucholtz, M., \& Hall, K. (2005). Identity and interaction: a sociocultural linguistic approach. Discourse Studies. 7 (4-5), 585-614.

Cook, H. M. (1990). The sentence-final particle ne as a tool for cooperation in Japanese conversation. In H, Hoji (ed.). Japanese Korean Linguistics. 20-44. Chicago: University of Chicago Press.

Cook, H. M. (1999). Language socialization in Japanese elementary schools: Attentive listening and reaction turns. Journal of Pragmatics, 31, 1443-1465.

Cook, H. M. (2008). Socializing identities through speech style: Learners of Japanese as a foreign language. Bristol: Multilingual Matters. 
Hashimoto, H. (1993). Language Acquisition of An Exchange Student within The Home stay Environment. Journal of Asian Pacific Communication. 209-224.

Hatasa, Y. A., Hatasa, K., \& Makino, S. (1998). Nakama: Introductory Japanese-communication, culture, context. Boston, MA: Houghton Mifflin Harcourt Pub.

Hatasa, Y. A., Makino, S., \& Hatasa, K. (2000). Nakama 2: Japanese communication, culture, context. Boston: Houghton Mifflin Company.

Kanagy, R. (1999). Interactional routines as a mechanism for L2 acquisition and socialization in an immersion context. Journal of Pragmatics. 31. 1467-1492.

Kurata, N. (2007). Language Choice and Second Language Learning Opportunities in Learners' Social Networks: A Case Study of an Australian Learner of Japanese. Australian Review of Applied Linguistics. 30 (1), 5.1-5.18.

Lam, W. S. E. (2004). Second Language Socialization in a Bilingual Chat Room: Global and Local Considerations. Language Learning \& Technology. 8 (3), 44-65.

Marriott, H. (1995). The Acquisition of Politeness Patterns by Exchange Students in Japan. In B. Freed. (ed.). Second Language Acquisition in a Study Abroad Context. 197-224. Amsterdam/Philadelphia: John Benjamins.

Matsuda, M. (2014). Kakite to yomite no zokusei, kankeisei no chushutsu: Facebook ni tanjobi meseeji wo kakukomu. Proceeding of the Annual Fall Conference of Society for Teaching Japanese as a Foreign Language 69-71.

Matsumoto, Y. (2002). Gender Identity and the Presentation of Self in Japanese, Gendered Practices in Language, (eds.) S. Benor, M. Rose, D. Sharma, J. Sweetland, Q. Zhang. Stanford, CA: CSLI Publications. 339-354. 2002.

Maynard, S. K. (1997). Japanese Communication: Language and Thought in Context. Honolulu: University of Hawaii Press.

Nakamura, K. (1999). The Acquisition of Formal and Informal Language by Japanese Preschool Children. A. Greenhill et al. (eds.). Proceedings the Annual Boston University Conference on Language Development. 23. 507-518.

Ohta, A. S. (1999). Interactional routines and the socialization of interactional style in adult learners of Japanese. Journal of Pragmatics. 31. 1493-1512.

Okamoto, S. (1997). Social context, linguistic ideology, and indexical expressions in Japanese. Journal of Pragmatics. 28. 795-817.

Okamoto, S. (2002). Ideology and Social Meanings: Rethinking the Relationship between Language, Politeness and Gender.

Okamoto, S. (2004). Ideology and Linguistic Practice and Analisus: Gender and Politeness in Japanese Revisited. In S. Okamoto. and J. S. Shibamoto. Smith. (ed.). Japanese Language, Gender, and Ideology. 38-56. Oxford: Oxford University Press.

Ozaki, W. (1998). "Gender-appropriate" language in transition: A study of sentence-final particles in Japanese. In SuzanneWertheim, Ashlee C. Bailey, and Monica CorstonOliver (eds.). Engendering communication Proceedings of the fifth Berkeley women and language conference. 427-437. Berkeley: Berkeley Women and Language Group. 
Schieffelin, B. B. and Ohes, E. (1986). Language socialization across culture. Cambridge: Cambridge University Press.

Siegal, M. (1994). Second-language learning, identity, and resistance: White women studying Japanese in Japan. Culture Performances, Proceedings of the Third Berkeley Women and Language Conference, Berkeley Women and Language Group, Berkeley, CA. 642-650.

Siegal, M. (1995). Individual differences and study abroad: Women learning Japanese in Japan. In B. Freed. (ed.). Second Language Acquisition in a Study Abroad Context. 223-244. Amsterdam/Philadelphia: John Benjamins.

Siegal, M. (1996). The Role of Leaner Subjectivity in Second Language Sociolinguistic Competency: Western Women Learning Japanese. Applied Linguistic. 17 (3). 356-382. 
